\title{
The Time-Varying Effect of Asset Prices on Turkey's Circular Economy
}

\author{
Mehmet Balcilar ${ }^{1,2}$ and Evrim Toren ${ }^{1, *}$ \\ 1 Department of Economics, Eastern Mediterranean University, Turkish Republic of Northern Cyprus, \\ Via Mersin 10, Famagusta 99628, Turkey; mehmet@mbalcilar.net \\ 2 Department of Economics, OSTIM Technical University, Ankara 06374, Turkey \\ * Correspondence: evrim.toren@emu.edu.tr
}

check for

updates

Citation: Balcilar, M.; Toren, E. The Time-Varying Effect of Asset Prices on Turkey's Circular Economy. Sustainability 2021, 13, 12373. https:// doi.org/10.3390/su132212373

Academic Editors: Kapila Liyanage and Ali Bastas

Received: 17 September 2021

Accepted: 5 November 2021

Published: 9 November 2021

Publisher's Note: MDPI stays neutral with regard to jurisdictional claims in published maps and institutional affiliations.

Copyright: (c) 2021 by the authors. Licensee MDPI, Basel, Switzerland. This article is an open access article distributed under the terms and conditions of the Creative Commons Attribution (CC BY) license (https:/ / creativecommons.org/licenses/by/ $4.0 /)$.

\begin{abstract}
The study aims to examine the effects of spillovers from stock prices on consumption and interest rates in Turkey. From the circular economy viewpoint, there should be sustainable consumption to achieve sustainable development with the help of consumers and other stakeholders. A time-varying vector autoregressive (TVP-VAR) model with stochastic volatility is used in the study. The aim is to obtain dynamics that stimulate growth, development, recession or change within the Turkish economy according to the emphases on circular economy. In order to analyze the relationship between real consumption, nominal interest rate and real stock prices, the TVP-VAR model is specified as a three-variable, time-varying model. The sample data that have been gathered from the Central Bank of the Republic of Turkey cover the period between Q1 1987 and Q3 2013. Overall, this study provides significant evidence of spillovers on consumption and interest rate during financial crises in Turkey, and the implications of monetary policy. In addition, the TVP model with stochastic volatility offers remarkable results regarding the influence of price shock on consumption in Turkey. However, we do not find any significant effect from interest rate to real consumption.
\end{abstract}

Keywords: circular economy; sustainable development; stochastic volatility; TVP-VAR

\section{Introduction}

The permanent income hypothesis is generally used to explain the relationship between an increase in wealth and consumption [1]: The increase in wealth can come from real (stock) asset price, real estate, or other financial assets. Camacho-Otero and Petterson [2] state that the sharing economy and collaborative consumption are two important issues which are used to intensify the use of assets and products in the economy. The sharing economy includes the companies that promote the right and opportunity to business models for the markets and users. Thus, there has to be the recirculation of goods, the escalation of using durable goods, the exchange of services and the allocation of productive assets in order to strengthen the well-being of the economy [3]. For Ertz, Durif and Arcand [4], the collaborative consumption involves the activities for the sustainable growth. In this respect, the consumers are defined as individuals who provide and obtain resources in the circular economy in order to facilitate the access to the assets.

Due to the increase in population and demand for goods, the inefficient depletion of resources, environmental impressions and high rates of wastes in various sectors, there is a necessity for a transition which leads to sustainable practices in the world [5]. Arsova et al. [6] contend that the transition towards the new model requires a marked and extensive change, collaboration, arrangement and teamwork between all stakeholders at all levels. The current economic systems generally use the linear economic model that is based on the abundance of resources and unlimited waste disposal. On the other hand, the circular economy means harnessing, mending and renovating products and substances efficiently and effectively. The term circular economy is a model of production and consumption 
which is illustrated through the well-known butterfly diagram. The diagram includes not only a biological cycle and a technological cycle at the centre but also the actors and activities in these cycles. The objectives are to provide maintenance and improvement for natural capital, the efficient and effective movement of products and parts and designing out unwanted or unusable material and substances [7]. The circular economy is also used to carry out a particular function for sustainable development. It works to the advantage of increased or optimal resource efficiency. Its main purpose is to encourage the development of harmony between the environment, economy and society [8-10]. It is important to note that the circular economy gradually necessitates the existence of economic activity which does not result in the compensation of finite resources. Thus, there is a process of changing from one condition to another in order to attain remarkable energy sources for the economic and natural capital.

According to Friedman [1], real stock (asset) price inflation increases the expected lifetime wealth of households and their consumption. The circular economy also aims to achieve sustainable development through sustainable consumption because it functions well by reducing, reusing, recycling, and recovering materials in two main processes, which are production/distribution and consumption. Thus, its favorable effect on the general excellence of standards, welfare and social equity cannot be overlooked [8]. The extant literature indicates that the relationship between consumption and the circular economy is increasing $[2-4,8]$. This has been noted in a growing number of studies conducted in recent years. Consumption in the context of circular economy and circular solutions has become an area of increased interest for researchers. However, to the best of the authors' knowledge, no work has been completed on the effect of asset prices on consumption and interest rates in Turkey. Moreover, questions regarding the time-varying effect of asset prices on Turkey's circular economy are not studied the literature. Therefore, Turkey has been chosen as the country of investigation because of the major structural changes and shifts that occur in its economy. It has also been selected to show how those changes and shifts can be interpreted according to the principles of circular economy. The main objective of this study is to analyze the impact of stock prices on consumption and interest rates in Turkey but also to examine whether asset price shock leads to simultaneous or delayed monetary policy responses, which might occur due to inflationary pressure. This paper further aims to demonstrate not only the influence of the spillover effect of stock price shocks on real consumption and nominal interest rate but also the dynamics of the general relationship among the variables in a small open economy. The paper is also an attempt to show some significant consumption and interest rate responses to stock market shock, particularly during crisis periods in the Turkish economy. The paper has three novelties. First, it examines the effect of asset prices and whether it leads to changes in the monetary policy instrument within an emerging economy, where such effects might be more influential compared to the advanced economies. Second, unlike the sparse literature on the asset price effect on Turkish economy, all using a constant parameter vector autoregressive (VAR) model, our study uses time-varying parameter vector autoregressive model, which better captures the changing dynamics of Turkish economy with frequent structural breaks. Third, our study allows time-varying volatility to appear explicitly in the estimation equation, making it possible to build a robust model that is capable of reflecting the Turkish economy's highly volatile time evolution.

The paper is organized as follows: Section 2 summarizes the relevant literature; Section 3 introduces a system of methods used in the TVP-VAR model, and Section 3.1 specifies properties of the data used; Section 4 presents the results of stock price shocks on consumption and interest rates; and Section 5 summarizes the basic findings and insights of the study.

\section{Literature Review}

As it is stated before, real stock (asset) price inflation increases the expected lifetime wealth of households and their consumption. In this respect, there is a wealth of literature 
on the broad-ranging international evidence for the consequences of major spillovers, from stock market to consumption, and not only in developed but also in developing countries. Lettau and Ludvingson [11] claim that the effect of fluctuations on the consumption-wealth ratio cannot be denied when estimating stock returns in the United States; they find that these fluctuations are very useful when real stock returns and excess returns on a Treasury bill rate are examined. Apergis and Miller [12] argue that stock market wealth affects real per capita consumption in the United States asymmetrically. Moreover, Fratzscher and Straub [13], in a study examining the relationship between asset prices and current account positions for 42 industrialized and emerging market countries, identify asset price shocks as news shocks in order to predict future productivity, and they conclude that the channels via wealth effects and the real exchange rate are very prominent when there is heterogeneity in the transmission.

Consistent with these studies, Koivu [14], analyzing the macroeconomic dynamics in China, contends that the loosening of China's monetary policy can lead to higher stock (asset) prices. In addition, a positive shock to residential prices in China increases household consumption when the effect of stock prices is very small. Sousa [15] also illustrates the impact of wealth on consumption, using the quarterly, seasonally adjusted data for the European area; Sousa's results confirm that wealth effects are particular for shares, currency and deposits and mutual funds. Thus, consumption reacts quickly and positively to the financial liabilities and mortgage loans in the European area.

Where Turkey is concerned, there are only limited studies, and these focus on the dynamics in the Turkish stock market and influences on consumption. Binay and Salman [16], for example, examine the wealth effects on total consumption when real estate increases by a single percentage point. From their research findings, they conclude that a single percentage point change in stock market indices increases consumption in durables. Aydede [17] investigates the impact of the unfunded social security system on consumption by using the Engle-Granger methodology. In addition, there are two papers-Uluengin and Yentürk [18] and Çimenoğlu and Yentürk [19]—that look at the behavior of the growth performance of the Turkish economy: Both studies use vector autoregression (VAR) models to show how private consumption depends on short-term capital inflows in the Turkish stock market. In terms of the effect of stock market changes on the interest rate, the economic theory predicts effects through changes in the supply and demand of funds. Campbell [20] argues that stock market and interest rates are related because variables because stock returns are linked to excess surplus returns via interest rate changes. On the relationship between the interest rate and consumption, economic theory emphasizes three channels (for a survey of the theory on this, see Elmendorf [21]). The first effect arises from the well-known intertemporal substitution effect. An increase in the interest rate should cause future consumption to increase and the current consumption to decrease. By increasing the future consumption gain for a dollar of saving, the interest rate increase makes the current consumption more costly relative to future consumption. Therefore, an interest rate increase encourages people to consume less today and save more. Second, an increase in the interest rate lowers the present discounted value of future consumption [22]. This means that increased interest rates imply that lower current amount of dollars are needed to finance a given level of future consumption. Therefore, future consumption becomes cheaper in real terms, leading to consume more today and save less. This effect is known as the income effect and its direction is opposite of the intertemporal substitution effect. Third, an increase in the interest rate also lowers the present discounted value of the future income, i.e., discounted present value of the lifetime wealth decreases. Higher interest rates also lower the present discounted value of the future capital income, representing a downward revaluation of accumulated financial assets. Due to competing intertemporal substitution effect and income and wealth effects, the effects of interest rates on consumption should be answered on empirical grounds. For instance, Campbell and Mankiw [23] find that interest rate changes lead to no significant change in consumption in the US. 
The Turkish stock market, Borsa Istanbul, is dominated largely by foreign investors. The fact that the market is largely dominated by foreign investors who held $60 \%$ of the publicly held stocks in their portfolios over the sample period of our study may indeed significantly eliminate the wealth effect on consumption. High foreign ownership on the other may increase the effect on the interest rate because of capital inflows and outflows due to foreign ownership. Capital inflows increases the demand for Turkish lira, creating an upward pressure on the interest rates. On the other hand, capital outflows increase the supply of Turkish lira and create downward pressure on the interest rate. How significant these effects should be assessed on empirical grounds. Our empirical results show that consumption responses positively to stock price appreciations up to a quarter and no significant effect remains afterwards. On the other hand, stock price appreciations do have a positive effect on the interest rate from the end of the first quarter to the beginning of the third quarter after the change occurs, implying a capital inflow effect due to more foreigners buying in the Turkish market.

In view of these articulations, the objective of this study is to analyze the impact of stock prices on consumption and interest rate in Turkey. Its methodology does not rely on constant parameter models, as is the case in the literature. Time-varying-parameter vector autoregressions (TVP-VARs) are very useful for the analysis of macroeconomic issues and offer a change or slight difference in the nature of the specific conditions within the economy [24]; in line with this view, the study uses the TVP-VAR model with stochastic volatility. This paper investigates not only the influence of the spillover effect of stock price shocks on real consumption and nominal interest rate but also the dynamics of the general relationship among the variables in a small open economy. The paper shows some significant consumption and interest rate responses to stock market shock particularly during crises periods. Therefore, large negative financial shocks lead to significant welfare reductions. Policymakers should be aware of the welfare consequences of the stock market crashes. Thus, our findings are important and contribute to the literature. In addition, this study is the first to apply the TVP-VAR model in Turkey to examine the spillover effect of real stock price shocks on real consumption and nominal interest rate by defending the necessity of the circular economy in Turkey because the activities that take place in circular economy could lead to re-industrialization, job creation and economic growth because of the new opportunities in various sectors through its expertise and technology.

\section{Methodology}

Quantifying and analyzing macroeconomic fluctuations has been one of the most important focuses in the economic literature. The pioneering article, "Macroeconomics and Reality" by Sims (1980), introduced a vector autoregression (VAR) for the investigation of macroeconomic fluctuations. Sims [25] contends that the VAR models enable the parameters to act according to a first-order random walk process; hence, the VAR models constitute not only temporary changes but also permanent changes to the parameters. This study uses the TVP-VAR model proposed by Primiceri [26] that includes stochastic volatility. According to Nakajima [24], the TVP-VAR model containing stochastic volatility provides for possible changes while examining the structure of the economy because it is both flexible and robust. The existence of stochastic volatility is valuable in the methodology of this study because the time-varying vector autoregressive model, with the help of Markov Chain Monte Carlo (MCMC) methods, prevents the results from having misspecifications.

The estimation of a time-varying parameter VAR model with stochastic volatility of the form can be expressed, after Nakajima [24], as follows:

$$
y_{t}=c_{t}+B_{1 t} y_{t-1}+\ldots+B_{s t} y_{t-s}+e_{t}, \quad e_{t} \sim N\left(0, \Omega_{t}\right),
$$

for $t=s+1, \ldots, T$, where $y_{t}$ is a $(k \times 1)$ vector of observed variables, $B_{1 t}, \ldots, B_{s t}$ are $(k \times k)$ matrices of time-varying coefficients and $\Omega_{t}$ is a $(k \times k)$ matrices of time-varying covariance matrix. Through the decomposition of $\Omega_{t}=A_{t}^{-1} \Sigma_{t} \Sigma_{t}^{\prime} A_{t}^{\prime-1}, A_{t}$ is a lower triangle matrix with diagonal elements equal to one and $\Sigma_{t}=\operatorname{diag}\left(\sigma_{1 t}, \ldots, \sigma_{k t}\right)$. $\beta_{t}$ is the 
stacked row vector of $B_{1 t}, \ldots, B_{s t} ; a_{t}$ is the stacked row vector of the free lower-triangular elements of $A_{t}$. In addition, $h_{t}$ is defined as $h_{t}=\left(h_{1 t}, \ldots, h_{k t}\right)^{\prime}$ and $h_{j t}=\log \sigma_{j t}^{2}$.

In this study, the time-varying parameters follow a random walk process:

$$
\begin{aligned}
& \beta_{t+1}=\beta_{t}+v_{\beta t}, \\
& a_{t+1}=a_{t}+v_{a t}, \\
& h_{t+1}=h_{t}+v_{h t},
\end{aligned}\left[\begin{array}{c}
\varepsilon_{t} \\
v_{\beta t} \\
v_{a t} \\
v_{h t}
\end{array}\right] \sim N\left(0,\left[\begin{array}{cccc}
I & 0 & 0 & 0 \\
0 & \Sigma_{\beta} & 0 & 0 \\
0 & 0 & \Sigma_{a} & 0 \\
0 & 0 & 0 & \Sigma_{h}
\end{array}\right]\right)
$$

for $t=s+1, \ldots, T$ with $e_{t}=A_{t}^{-1} \Sigma_{t} \varepsilon_{t}$, where $\Sigma_{\beta}, \Sigma_{a}$ and $\Sigma_{h}$ are diagonal, $\beta_{s+1} \sim$ $N\left(\mu_{\beta_{0}}, \Sigma_{\beta_{0}}\right), a_{s+1} \sim N\left(\mu_{a_{0}}, \Sigma_{a_{0}}\right), h_{s+1} \sim N\left(\mu_{h_{0}}, \Sigma_{h_{0}}\right)$.

In order for the identification of the shocks, let $\operatorname{var}\left(e_{t}\right)=H_{t}$. Then, we factor the variance-covariance matrix as:

$$
\operatorname{var}\left(e_{t}\right)=\Omega_{t}=A_{t}^{-1} H_{t} A_{t}^{\prime-1}
$$

These time varying matrices are defined as:

$$
H_{t}=\left[\begin{array}{ccc}
h_{1, t} & 0 & 0 \\
0 & h_{2, t} & 0 \\
0 & 0 & h_{3, t}
\end{array}\right] \text { and } A_{t}=\left[\begin{array}{ccc}
1 & 0 & 0 \\
\alpha_{21, t} & 1 & 0 \\
\alpha_{31, t} & \alpha_{32, t} & 1
\end{array}\right]
$$

Thus, we identify all three shocks by imposing three restrictions on the matrix $A_{t}$ in Equation (4) (see, e.g., [24,26]). The triangular identification of the VAR in Equation (4) is consistent with the focus of the paper. Our interest is to analyze how changes in stock prices, as a measure of increase in asset endowment, affect interest rates and consumption. The restrictions assume that asset price changes will first induce their effects in money markets, and interest rate changes will be the first to respond to the conditions in money markets. Second, consumption will respond to both interest rate changes and changes in asset levels. This identification scheme is consistent with the economic theory and focus of the paper. However, how well the theory fits reality is an empirical question, which we take up as the focus of this study.

The parameters of the TVP-VAR model in Equations (1)-(4) are estimated using the Bayesian approach of Primiceri [26] and Nakajima [24]. The existence of a Bayesian inference enables estimation of the TVP-VAR models using MCMC methods; the objective of the MCMC methods is to evaluate the joint posterior distributions of the parameters of interest [24]. The parameters of the TVP-VAR model are estimated using Bayesian inference via MCMC. In the application of the MCMC method, the goal is to assess the joint posterior distributions of the parameters of the model defined in Equations (1) to (4). In order for the evaluation of joint posterior distributions, one needs to set certain priors for all the unknown parameters in the model, except for the time-varying state variables, which are estimated recursively given the initial states. Following Nakajima [24], we use the following priors: $\Sigma_{\beta} \sim \operatorname{IW}(25,0.01 \mathrm{I}),\left(\Sigma_{a}\right)_{i}^{-1} \sim \mathrm{G}(4,0.02),\left(\Sigma_{h}\right)_{i}^{-1} \sim \mathrm{G}(4,0.02)$, where $\left(\Sigma_{a}\right)_{i}$ and $\left(\Sigma_{h}\right)_{i}$ are the $i$-th diagonal elements of $\left(\Sigma_{a}\right)_{i}$ and $\left(\Sigma_{h}\right)_{i}$, respectively. IW and G represent the inverse Wishart and gamma distributions, respectively. For the initialization of the TVPs, we use flat priors by setting $\mu_{\beta_{0}}=\mu_{a_{0}}=\mu_{h_{0}}=0$ and $\Sigma_{\beta_{0}}=\Sigma_{\mathrm{a}_{0}}=\Sigma=10 \times I$.

\subsection{Data Collection and Data Analysis}

The sample data which have been gathered from the Central Bank of the Republic of Turkey is examined in this study. Data between the period Q1 1987 and Q3 2013 is used to estimate the TVP-VAR model, which includes three variables-real consumption, real stock prices and nominal interest rate. The aim is to evaluate macroeconomic dynamics in Turkey.

The unit root tests which are performed throughout the analysis are Augmented Dickey-Fuller [27] (ADF), Phillips-Perron [28] (PP), Dickey-Fuller with generalized least 
squares detrending (DF-GLS), the Kwiatkowski, Phillips, Schmidt and Shin [29] (KPSS), the Elliot, Rotherberg and Stock (ERS) [30] point optimal test, the Ng-Perron [31] modified versions of the PP (NP-MZt) test and the ERS point optimal (NP-MPt) test. All unit root tests reported in Table 1 uniformly fail to reject the nonstationarity of all three series in the levels, but the tests reject the nonstationarity in the first differences. Therefore, all three series are nonstationary.

Table 1. Unit root tests.

\begin{tabular}{|c|c|c|c|}
\hline & Real Stock Price & $\begin{array}{c}\text { Real } \\
\text { Consumption }\end{array}$ & $\begin{array}{c}\text { Nominal Interest } \\
\text { Rate }\end{array}$ \\
\hline ADF & & & \\
\hline Level with Constant and Trend & -3.38 & -2.85 & -2.27 \\
\hline Level with Constant & -0.45 & -0.56 & -0.10 \\
\hline $\begin{array}{c}\text { First Differences with Constant } \\
\text { and Trend }\end{array}$ & $-8.22 * * *$ & $-10.12^{* * *}$ & $-10.29 * * *$ \\
\hline $\begin{array}{l}\text { First Differences with Constant } \\
\text { PP }\end{array}$ & $-8.71^{* * *}$ & $-10.07^{* * *}$ & $-11.38^{* * *}$ \\
\hline Level with Constant and Trend & -0.43 & -3.09 & -1.63 \\
\hline Level with Constant & -0.84 & -0.46 & -0.11 \\
\hline $\begin{array}{l}\text { First Differences with Constant } \\
\text { and Trend }\end{array}$ & $-8.22 * * *$ & $-10.43^{* * *}$ & $-13.43^{* * *}$ \\
\hline $\begin{array}{l}\text { First Differences with Constant } \\
\text { DF-GLS }\end{array}$ & $-8.95^{* * *}$ & $-10.45^{* * *}$ & $-20.45^{* * *}$ \\
\hline Level with Constant and Trend & -2.19 & -2.85 & -1.04 \\
\hline Level with Constant & 1.67 & -1.34 & -0.16 \\
\hline $\begin{array}{c}\text { First Differences with Constant } \\
\text { and Trend }\end{array}$ & $-7.29^{* * *}$ & $-4.37^{* * *}$ & $-10.17^{* * *}$ \\
\hline $\begin{array}{l}\text { First Differences with Constant } \\
\text { KPSS }\end{array}$ & $-8.27^{* * *}$ & $-4.38^{* * *}$ & $-11.01^{* * *}$ \\
\hline Level with Constant and Trend & $0.82 * * *$ & $0.17^{* * *}$ & $0.88^{* * *}$ \\
\hline Level with Constant & $0.87 * * *$ & $1.15^{* * *}$ & $0.30^{* * *}$ \\
\hline $\begin{array}{l}\text { First Differences with Constant } \\
\text { and Trend }\end{array}$ & 0.03 & 0.05 & $0.14^{*}$ \\
\hline $\begin{array}{c}\text { First Differences with Constant } \\
\text { ERS }\end{array}$ & 0.04 & 0.05 & $0.36^{*}$ \\
\hline Level with Constant and Trend & 5.81 & 6.36 & 5.72 \\
\hline Level with Constant & 162.67 & 6.91 & 17.18 \\
\hline $\begin{array}{l}\text { First Differences with Constant } \\
\text { and Trend }\end{array}$ & $2.07^{* * *}$ & $2.30^{* * *}$ & $0.72^{* * *}$ \\
\hline $\begin{array}{l}\text { First Differences with Constant } \\
\text { NP-MZt }\end{array}$ & $1.72 * * *$ & $0.81^{* * *}$ & $1.76^{* * *}$ \\
\hline Level with Constant and Trend & -2.19 & -2.66 & -2.70 \\
\hline Level with Constant & 1.83 & -1.55 & -0.10 \\
\hline $\begin{array}{l}\text { First Differences with Constant } \\
\text { and Trend }\end{array}$ & $-3.64^{* * *}$ & $-3.43^{* * *}$ & $-7.80^{* * *}$ \\
\hline $\begin{array}{l}\text { First Differences with Constant } \\
\text { NP-MPt }\end{array}$ & $-4.97^{* * *}$ & $-3.57^{* * *}$ & $-2.46^{* * *}$ \\
\hline Level with Constant and Trend & 5.75 & 6.44 & 5.77 \\
\hline Level with Constant & 119.06 & 4.69 & 16.48 \\
\hline $\begin{array}{l}\text { First Differences with Constant } \\
\text { and Trend }\end{array}$ & $3.46^{* * *}$ & $3.88^{* * *}$ & $0.75^{* * *}$ \\
\hline First Differences with Constant & $0.61^{* * *}$ & $0.97 * * *$ & $1.77^{* * *}$ \\
\hline
\end{tabular}

Note: The table reports unit root tests for the level and first differences of the real stock price (RSP) real consumption $(R C)$ and nominal interest rates $(R)$. The null hypothesis in "stationarity" for the KPSS test while it is "nonstationarity" for the other tests. ${ }^{* *}$, and ${ }^{*}$ denote rejection of the test at the $1 \%$ and $10 \%$ level, respectively.

The time-series data for real consumption and real stock prices in Turkey is found to be non-stationary; therefore, the corresponding growth rates of these variables are obtained and named as DRSP and DRC for the research findings. Using the unit root tests, 
the nominal interest rate values is also found to be nonstationary, and the change in the nominal interest rate is specified as $D R$.

Since all variables are nonstationary, they should be checked for cointegration in order to determine the correct model specification. We use multivariate VAR-based trace and maximal eigenvalue tests of Johansen [32,33] and Johansen and Juselius [34] in order test for cointegration. We further check the robustness of the Johansen tests with the bounds test approach based on autoregressive distributed autoregressive (ARDL) of Pesaran, Shin and Smith [35] using the response surface critical values provided by Kripfganz and Schneider [36]. In order test for cointegration, we first use lag-length tests such as LR test statistics, the Akaike information criterion and the Schwarz information criterion to determine the lag order of the VAR. We use Akaike information criterion to select the lag length since we have a relatively small sample and Akaike information criterion has better performance in small samples [37]. The order of the VAR is determined as four by the Akaike information criterion, which is used in the cointegration test and the TVP-VAR model estimation.

The results of the Johansen cointegration tests are reported in Table 2. We use a constant in the VAR specification of Johansen and Juselius [34] in order to test for cointegration. Based on the results reported in Table 2, we do not reject the null hypothesis of "no cointegration" at the 5 percent level by both the trace and maximum eigenvalue tests. Both the trace and maximal eigenvalue tests statistics uniformly indicate that the real stock prices, real consumption and nominal interest rate series maintain no cointegration relationship at the $5 \%$ significance level.

Table 2. Johansen cointegration test results.

\begin{tabular}{ccccc}
\hline $\begin{array}{c}\text { Hypothesized } \\
\text { Cointegration Vectors }\end{array}$ & Eigenvalue & Test Statistic & $\mathbf{5 \%}$ Critical Value & $\boldsymbol{p}$-Value \\
\hline None & 0.1325 & Trace Test & \\
At most 1 & 0.0887 & 24.9032 & 29.7971 & 0.1649 \\
At most 2 & 0.0000 & 9.8399 & 15.4947 & 0.2932 \\
& Maximal Eigenvalue Test & 3.8415 & 0.9937 \\
None & 0.1325 & 15.0634 & 21.1316 & 0.2845 \\
At most 1 & 0.0887 & 9.8398 & 14.2646 & 0.2227 \\
At most 2 & 0.0000 & 0.0001 & 3.8415 & 0.9937 \\
\hline
\end{tabular}

Note: The table reports the Johansen trace and maximal eigenvalue tests for zero to two cointegration vectors among the three series.

Both the trace and maximal eigenvalue tests show that the real stock prices, real consumption and the nominal interest rate series are not cointegrated. Therefore, in order obtain a stable TVP-VAR model, the variables are first differenced, and the TVP-VAR model is specified with the vector $y_{t}=\left(D S P_{t}, D R_{t}, D R C_{t}\right)^{\prime}$.

We use the bounds tests to check the robustness of Johansen cointegration test results. The results of bounds tests for cointegration are reported in Table 3 . The F-test and $t$-test type bounds tests are performed using two different deterministic component specifications, the one with only a constant and the other with a constant and trend. The table also reports upper bounds for critical values when forcing variables are purely integrated of order one, i.e., I(1), and lower bounds for critical values when forcing variables are purely integrated of order zero, i.e., I(0). Both F-test and $t$-test do not reject the null hypothesis of no cointegration at the $5 \%$ level when only a constant is used in the deterministic specification. When a constant and trend are used in the deterministic component, the $t$-test does not reject the null of no cointegration at the $5 \%$ level, but the $F$-test is inconclusive. Thus, the bounds tests confirm the multivariate Johansen cointegration tests, indicating no cointegration among the three variables. 
Table 3. Bonds tests for cointegration.

\begin{tabular}{|c|c|c|c|c|c|c|c|}
\hline \multirow[b]{3}{*}{ Test Type } & \multirow[b]{3}{*}{ Estimate } & \multicolumn{6}{|c|}{ Critical Values } \\
\hline & & \multicolumn{2}{|c|}{$10 \%$} & \multicolumn{2}{|c|}{$5 \%$} & \multicolumn{2}{|c|}{$1 \%$} \\
\hline & & $\mathrm{I}(0)$ & $\mathrm{I}(\mathbf{1})$ & $\mathrm{I}(0)$ & $\mathrm{I}(\mathbf{1})$ & $\mathrm{I}(0)$ & I(1) \\
\hline \multicolumn{8}{|c|}{ Deterministic Specification: Constant } \\
\hline F-test & 2.777 & 3.162 & 4.179 & 3.823 & 4.942 & 5.309 & 6.626 \\
\hline$t$-test & -1.534 & -2.539 & -3.188 & -2.852 & -3.525 & -3.464 & -4.170 \\
\hline \multicolumn{8}{|c|}{ Deterministic Specification: Constant and Trend } \\
\hline F-test & $5.733 *$ & 4.230 & 5.154 & 4.977 & 5.984 & 6.627 & 7.791 \\
\hline$t$-test & -2.688 & -3.127 & -3.662 & -3.428 & -3.986 & -4.019 & -4.611 \\
\hline
\end{tabular}

The period covered in our study corresponds several crises in the Turkish economy, such as the 1994 debt crises, 1997-1998 Asian crises, 2001 crises and 2007-2008 subprime crises. Such significant crises may lead to parameter instabilities in the estimated VAR models or ARDL models, making the inference based on these constant parameter models invalid. In order to check for the parameter instability, we use CUSUM and CUSUM of squares (CUSUMSQ) tests performed on each equation of the VAR model.

Figure 1 presents the CUSUM and CUSUMSQ tests, which are based on recursively estimated parameters. The CUSUM test is known to have better power when structural break is in the intercept of the regression equation while CUSUMSQ test has better power when structural break affects the slope of the regression equation or the variance of the error term. Panels A, B and C of Figure 1 presents CUSUM and CUSUMSQ tests for consumption, stock price and interest rate equations, respectively. Both the CUSUM and CUSUMSQ tests indicate that parameters of all three equations display instability at the $5 \%$ significance level for various time periods. Thus, inference based on a constant parameter model would be incorrect, a result that supports the preference of the TVP-VAR model.

(a)

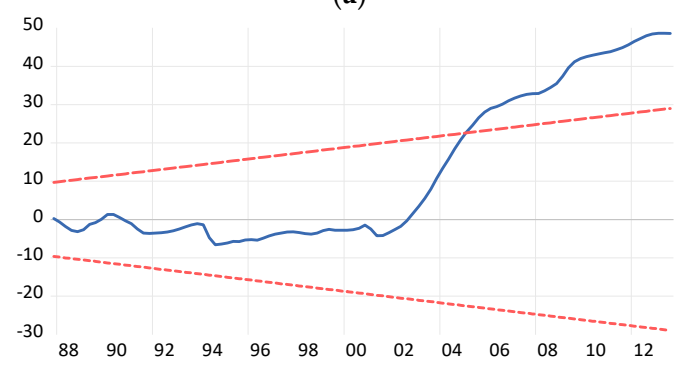

— cusum ---- 5\% significance Panel B: Stock price equation

(c)

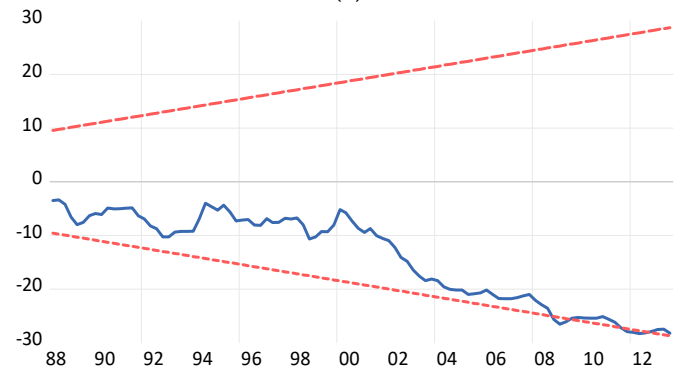

— CUSUM ---. 5\% significance
Panel A: Consumption Equation

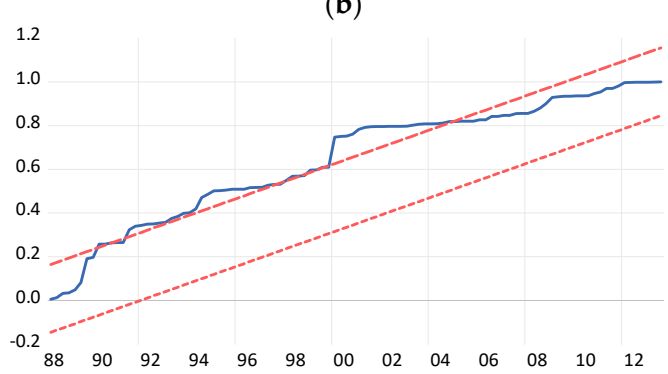

_ CUSUM of Squares ----. 5\% Significance

(d)

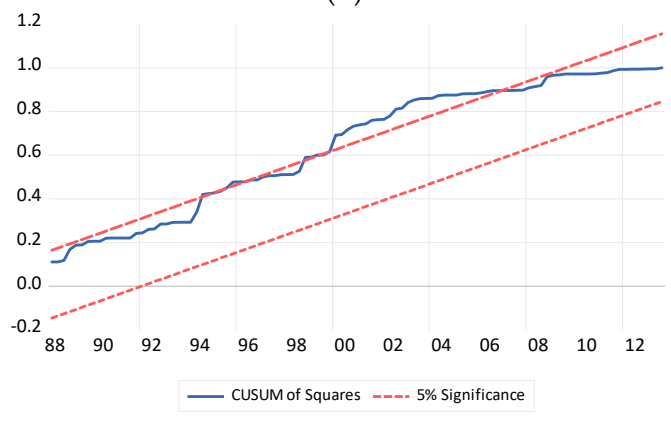

Figure 1. Cont. 
(e)

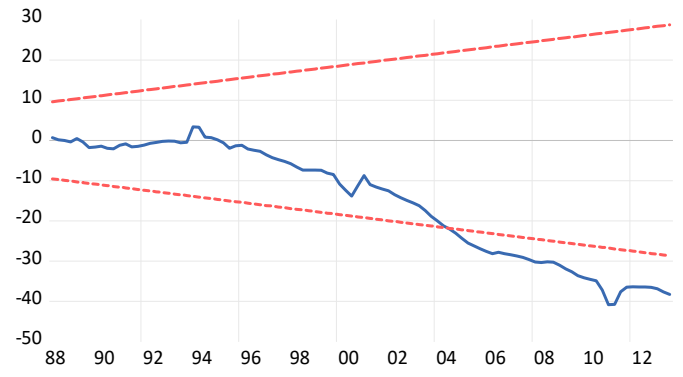

— CUSUM ---.. 5\% Significance
Panel C: Interest rate equation

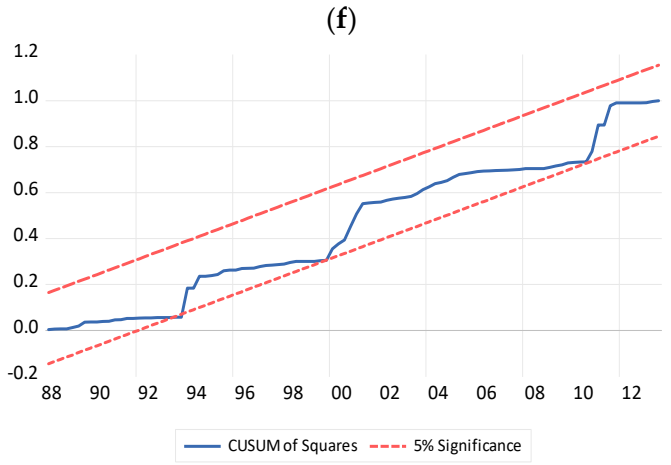

Figure 1. CUSUM tests for parameter stability: (a) CUSUM test; (b) CUSUM of squares test; (c) CUSUM test; (d) CUSUM of squares test; (e) CUSUM test; (f) CUSUM of squares test.

\section{Results}

The posterior estimates are computed by drawing $M=10,000$ samples. Table 4 presents the results for the means, standard deviations, 95\% credible intervals, the convergence diagnostics (CD) of Geweke [38] and the inefficiency factors of parameters of the model. The CD statistics confirm that the null hypothesis of the convergence to the posterior distribution is not rejected at the 5 percent level of significance. Therefore, we conclude that 10,000 posterior draws were sufficient for the accuracy of the estimates. When the efficiency factors are taken into consideration, Table 3 shows that, in general, they are not so high. Since the 95 percent confidence intervals include the estimated posterior mean for every parameter in the TVP-VAR model, the MCMC algorithm efficiently provides posterior draws.

Table 4. Estimation results of the parameters.

\begin{tabular}{ccccccc}
\hline Parameter & Mean & Std. Dev. & $\mathbf{9 5 \%} \mathbf{U}$ & $\mathbf{9 5 \%} \mathbf{L}$ & $\mathbf{C D}$ & Inefficiency \\
\hline$\left(\Sigma_{\beta}\right)_{1}$ & 0.1258 & 0.0638 & 0.0545 & 0.3002 & 0.959 & 158.98 \\
$\left(\Sigma_{\beta}\right)_{2}$ & 0.0809 & 0.0431 & 0.0247 & 0.1924 & 0.177 & 129.10 \\
$\left(\Sigma_{a}\right)_{1}$ & 0.0056 & 0.0015 & 0.0035 & 0.0092 & 0.950 & 46.28 \\
$\left(\Sigma_{a}\right)_{2}$ & 0.0056 & 0.0015 & 0.0035 & 0.0095 & 0.000 & 20.24 \\
$\left(\Sigma_{h}\right)_{1}$ & 0.0054 & 0.0014 & 0.0033 & 0.0087 & 0.981 & 30.77 \\
$\left(\Sigma_{a}\right)_{2}$ & 0.0059 & 0.0017 & 0.0036 & 0.0101 & 0.012 & 37.06 \\
\hline
\end{tabular}

Figure 2 presents the data of the three variables, which are the nominal interest rate, the real stock prices and the real consumption $(D R, D R S P, D R C)$, at the top of the figure. The corresponding posterior estimates of the stochastic volatility are seen at the bottom of the figure. The nominal interest rates are found to exhibit the most stochastic volatility because Turkey had a long chronic high and fluctuating inflation history from the beginning of the sample until the mid-2000s, making the nominal interest rate highly volatile. Domestic and international macroeconomic instabilities resulted in four major crises between 1990 and 2011. According to the results, fluctuations in consumption growth in Turkey begins to be highly volatile in the middle of the sample period and peaks around in 2001. In addition, the fluctuations in consumption are also highly volatile in 1994 and 2007 because of the financial crisis and global crisis, respectively. The volatility of consumption is low and stable both for the early period of the sample until 1994, and for the period between 2001 and 2008. The low stochastic volatility can be regarded as reflecting certainty in the consumption period, due to the economic and political environment in Turkey. The real stock returns represent high fluctuations at the beginning of the sample. The highest volatility is observed around 1994 because of the decrease in economic crises in this period. 

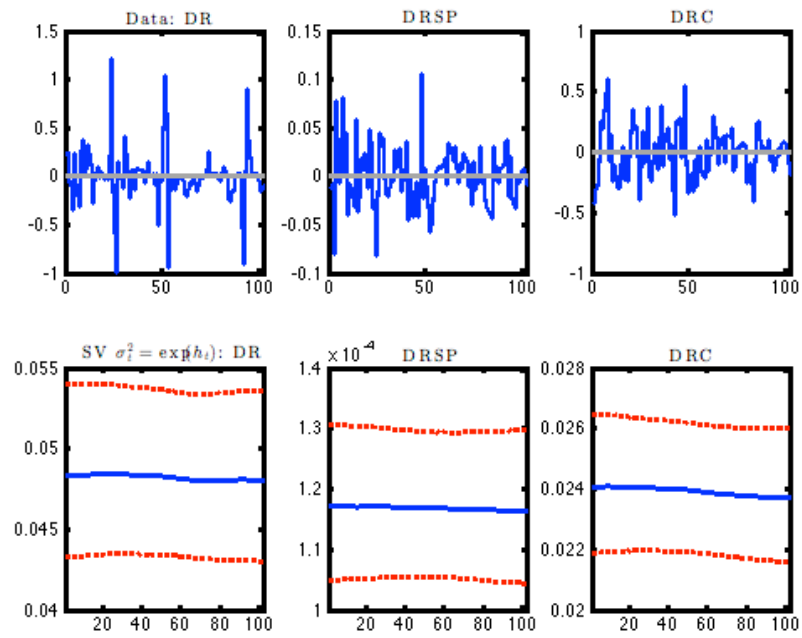

Figure 2. The posterior estimates in the TVP-VAR model.

While simulating the impulse responses in the TVP-VAR model, this study computes the impulse responses not only by fixing initial shock size as equal to the time series average of stochastic volatility for the sample but also by analyzing the concurrent relations at each point. The aim is to maintain the comparability of the model [24]. Figure 3 presents the time-varying responses of the real consumption, real stock prices and nominal interest rate, which are influenced by a shock to real stock price for one step ahead. The mean of the posterior draws is presented with the 16th and 84th percentiles. The impact of a shock to real stock price on itself is generally positive, but there are periods with negative responses as well. The effect is always significant for the one-quarter ahead horizon. However, the positive real stock price shock affects consumption positively for the whole period. The influence of a price shock on consumption is observed as significant at 1-step ahead. When the nominal interest rate is taken into consideration, this variable shows an interesting behavior. An increase in the real stock price leads to no significant effect for interest rate responses at the one-step ahead horizon. Moreover, the effect of interest rate shock on consumption is negative and significant until mid-1990, but it becomes insignificant afterwards. In addition, when there is a shock to nominal interest rate, the impact on the interest rate itself is positive, as shown in Figure 3.
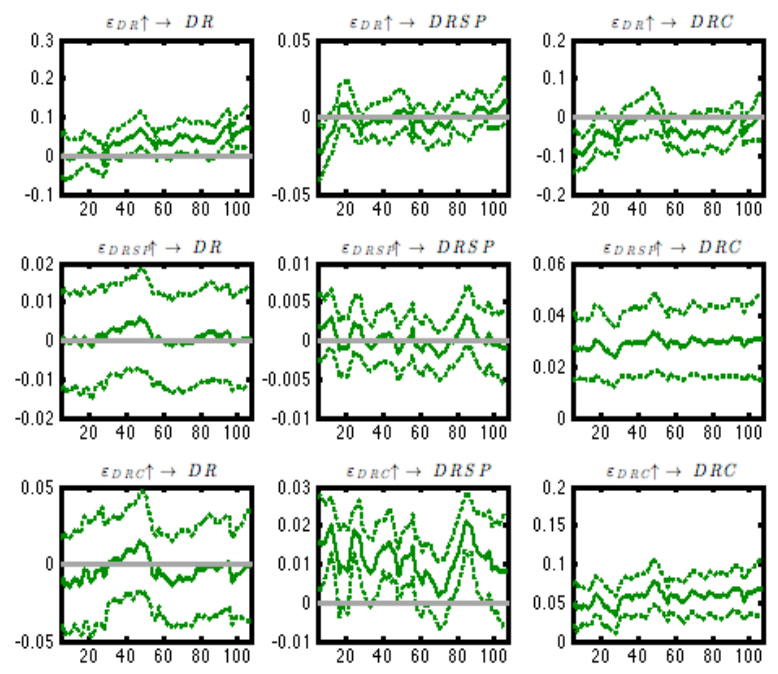

Figure 3. Impulse responses of the model for 1-step ahead.

As is seen in Figure 4, when a real stock price follows a shock, in general, this shock does not influence the stock price itself, as the responses are insignificant. However, a positive shock to real stock price has a positive impact on nominal interest rate. On the 
other hand, where consumption is concerned, for the four quarters ahead, the impulse responses are initially negative, and then become positive, especially for the period around 1993, 2000 and 2008. However, the response of the consumption to stock market shock is generally insignificant.
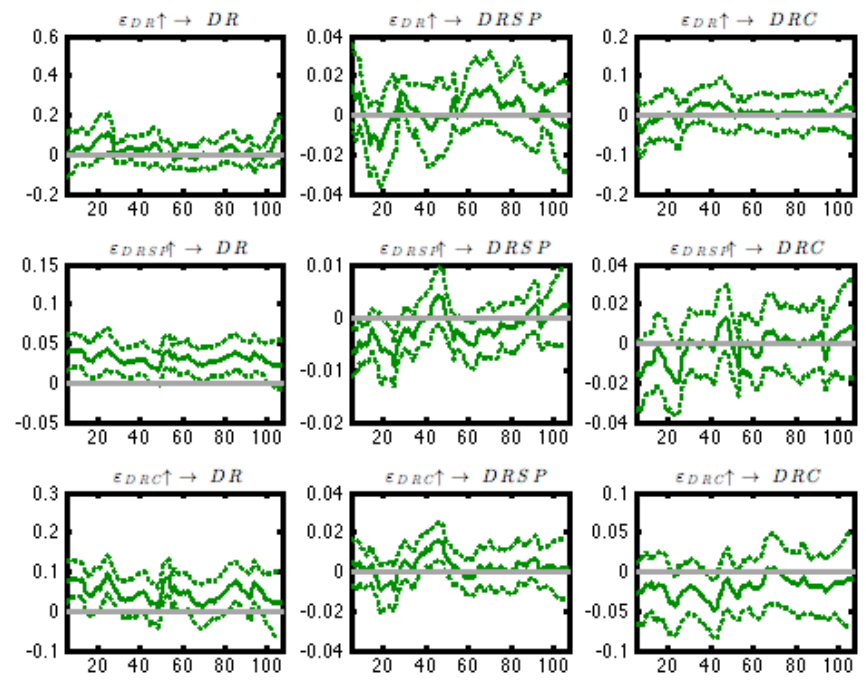

Figure 4. Impulse responses of the model for 4-steps ahead.

Figure 5 displays the impulse responses at eight-steps ahead. If a real stock price is experienced with a positive shock, the impulse responses illustrate the positive effect on stock price. However, the effect is again not significant. In addition, a positive shock to real stock price has interesting effects, both on consumption and interest rate. As is seen in Figure 5, although, in general, the impulse responses are mostly positive, they are insignificant over the whole sample period.
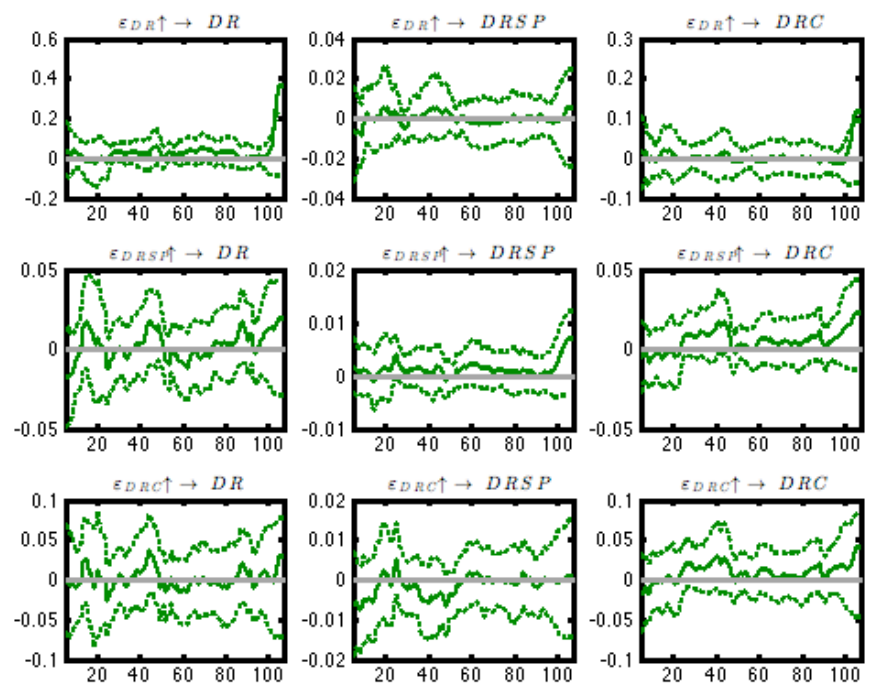

Figure 5. Impulse responses of the model for 8-steps ahead.

In Figure 6, the impulse responses depict a pattern dissimilar to the 12-quarters ahead horizon, because the effects are not greater at longer horizons. When the time-varying response trajectories for the three variables are considered, the positive shock of real stock price results in significant influences on consumption and interest rate. 

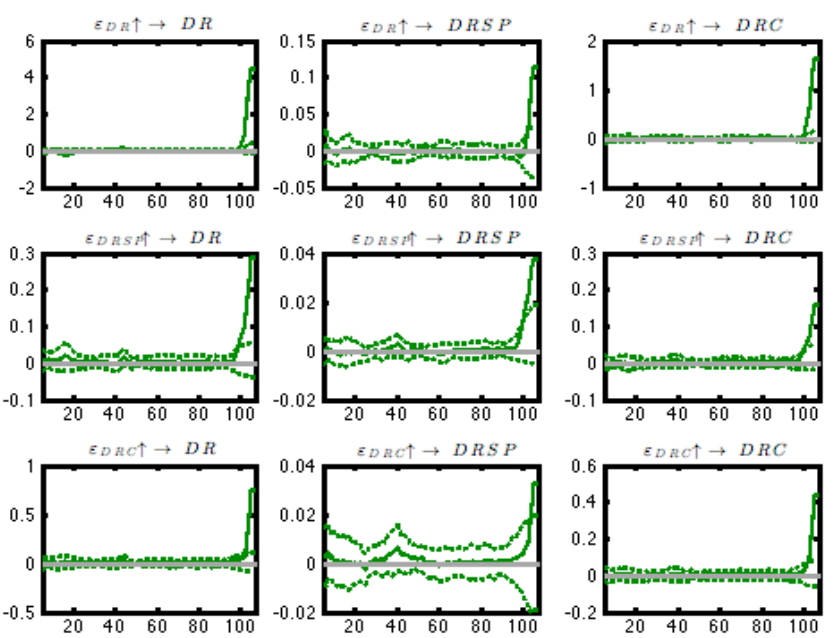

Figure 6. Impulse responses of the model for 12-steps ahead.

Figure 7 presents the impulse responses of the model at Q1 1994. For Rodrik [39], a misguided attempt to keep interest rate low resulted in a sudden capital outflow in Turkey in this year. Before the crisis hit the economy, a general picture of the Turkish economy was based on the poor fiscal stance, high current account deficit, the overvaluation of the Turkish lira, the illiquidity of the government according to international standards and the weak banking sector. For Özatay [40], the crisis was unexpected because of the stable foreign exchange reserve levels and interest differentials in the period before the crisis.
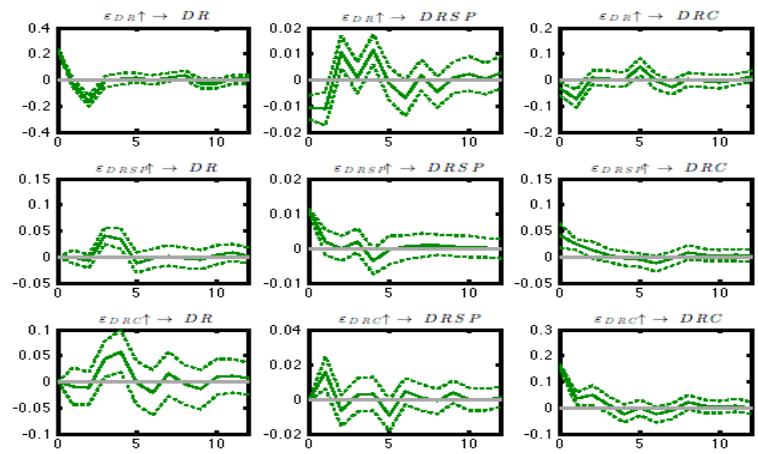

Figure 7. Impulse responses of the model at Q1 1994.

In light of these statements, the impulse responses for 1994 in Figure 7 confirm that when the real stock price experiences a positive shock, the impact on itself is positive and then becomes insignificant in two quarters. This positive shock also leads to an increase in consumption, followed by a decrease in consumption, but the decrease is insignificant. However, the interest rate, which follows a real stock price shock, depicts a positive significant effect from the second to the fifth quarter. We point out that the actual stock market shock was a large negative shock, thus, these effects on consumption will be negative for a negative shock.

Figure 8 illustrates impulse responses of the model in Q4 2000 resulting from another destructive financial crisis, which is more severe than the 1994 crisis. The Turkish economy was in a severe political and financial crisis on 19 February 2001. Özatay and Sak [41] contend that the public sector borrowing requirement, the ratio of public debt to GNP, the current account deficit, the inflation level and the ratio of the liabilities of the financial sector were very high in the last quarter of 2000. Thus, in Figure 8, when there is a positive shock to real stock price, the effect on itself generally represents a positive response. The effect is also significant for the entire year. This positive shock also leads consumption to respond positively, so the effect on consumption is significant in Q1 2000. If the nominal 
interest rate is concerned, the impulse responses are initially insignificant, and then they become positive and significant from the second to the fifth quarters after the shock.
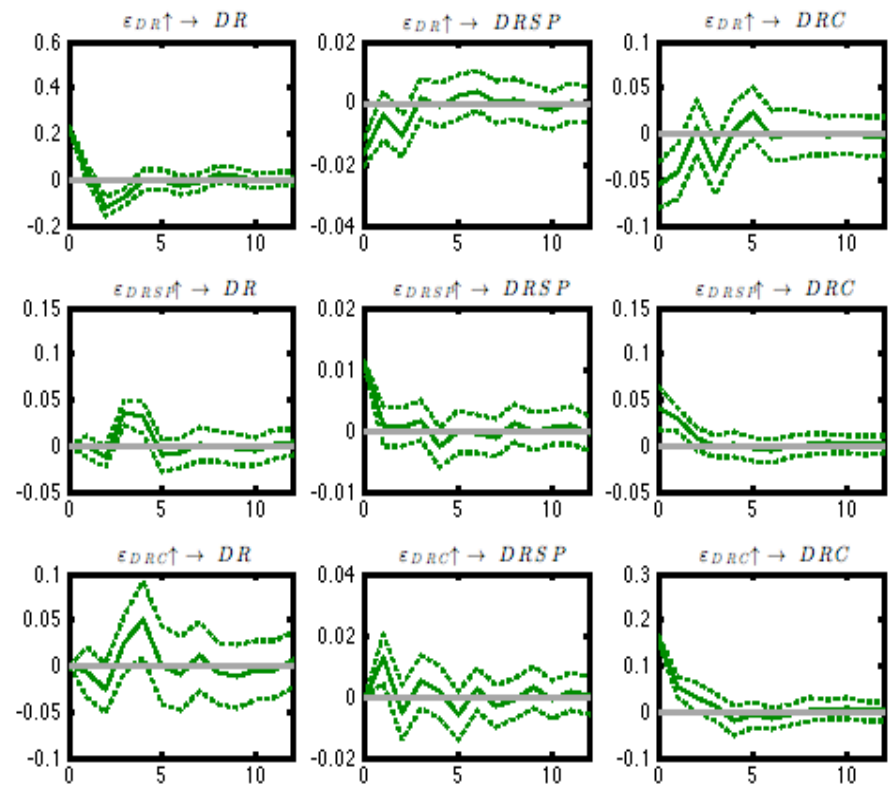

Figure 8. Impulse responses of the model at Q4 2000.

Figure 9 provides impulse responses of the model in 2007, caused by a great disturbance in the United States' financial markets in that year. According to Krugman [42], the financial troubles which led to the crisis in the financial markets in the U.S. in 2007 consequently created a full-fledged global crisis in 2008. This crisis developed gradually and evolved into a global crisis that significantly hit the Turkish economy. In this view, Figure 9 presents the impulse responses for the three variables of the concern following positive shocks. As is seen, when there is a shock to the real stock price, consumption is affected positively. This positive shock also leads to an increase in the stock price's response. However, the nominal interest rate initially has insignificant impulse responses and then positive and significant responses for three quarters from the second to the fifth quarters after the shock is realized.
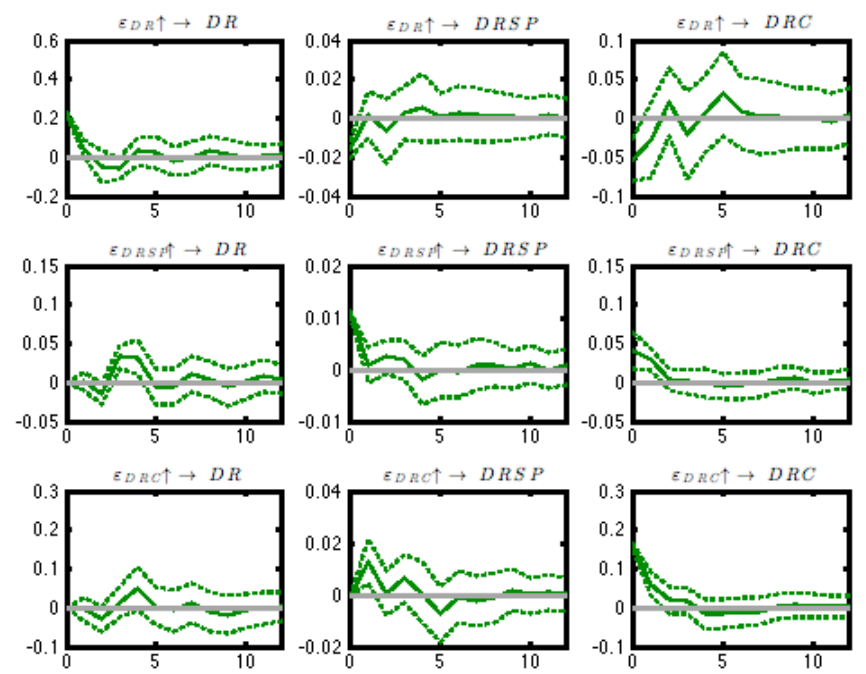

Figure 9. Impulse responses of the model in Q1 2007.

Figure 10 shows impulse responses of the TVP-VAR model in Q1 2011 caused by the adverse effect on the Turkish economy of the United States' debt-ceiling crisis of 2011. 
A shock to the real stock price influences consumption positively because the effect is significant. When there is a shock to the real stock price, the impulse responses are initially positive and then become insignificant for both consumption and stock prices. The effect is not always significant in 2011. However, when the nominal interest rate is taken into consideration, a positive shock to real stock price affects interest rate positively for a short period from the second to the fifth quarter after shock is realized.
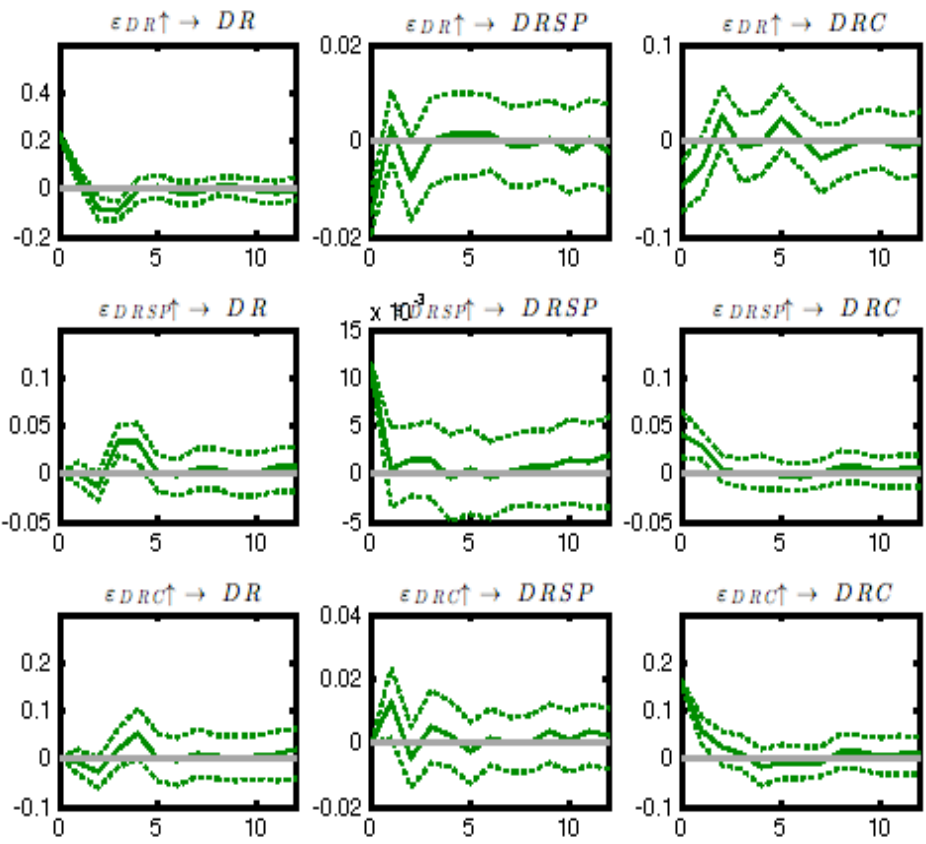

Figure 10. Impulse responses of the model in Q1 2011.

\section{Conclusions}

In this study, a three-variable TVP-VAR model, which includes stochastic volatility, is used to show the impact of real stock prices on real consumption and nominal interest rate for Turkey over the quarterly period of Q1 1987-Q3 2013. The study provides the significant spillovers for consumption and interest rate caused by the financial crises and implications of monetary policy in Turkey. The results of the research findings confirm that a positive shock to real stock price positively influences consumption in Turkey. The effect is significant, especially for the one-step-ahead horizon. In addition, the impulse responses of the model for the years 1994, 2000, 2007 and 2011 offer significant results regarding the impact of stock prices on interest rate and consumption. It is also important to note that there is an existence of sustainable consumption for the sustainable development in Turkey because the liable consumers have a willingness to perform the circular economy for the general excellence of standard, welfare and social equity. In this respect, there should be always close collaboration between all stakeholders at all levels while encouraging the sustainable development in the Turkish economy. Overall, this study suggests the usage of the time-varying model with stochastic volatility to capture variability for the parameters of consumption and interest rate.

Based on the findings from the TVP-VAR model, the study suggests that Turkey should have a core structure of institutions and authorities for policies, if the country is serious about controlling uncertainty and volatility. Supportive policies should be encouraged to promote welfare growth by focusing on controlling inflation, implementing efficient and effective foreign exchange efforts, improving the national budget, raising revenue, using a transparent system of public expenditure and introducing a coherent monetary policy framework that can deal with the inflationary effects in Turkey. The instability of the wealth effect and the changing effects on interest rates requires macroprudential policies supplemented by regulations that preserve budgetary actions, central bank facilities, 
strategies of international and domestic trade operations and governance authorities to ensure Turkey's well-being in terms of economic stability. When these developments have occurred, the effect of fluctuations can be reduced to the greatest extent.

In future research, it will be interesting to build on our empirical research and compare the Turkish economy with the BRICS countries. Such an analysis for the time-varying effect of asset prices on consumption and interest rate in both Turkey and the BRICS countries can be beneficial for policymakers in these countries.

Author Contributions: Conceptualization, M.B.; methodology, M.B.; software, M.B.; validation, M.B.; formal analysis, M.B.; investigation, E.T.; resources, M.B. and E.T.; data curation, M.B. and E.T.; writing—original draft preparation, M.B. and E.T.; writing-review and editing, M.B. and E.T.; visualization, M.B.; supervision, M.B.; project administration, M.B.; funding acquisition, M.B. and E.T. All authors have read and agreed to the published version of the manuscript.

Funding: This research received no external funding.

Institutional Review Board Statement: Not applicable.

Informed Consent Statement: Not applicable.

Data Availability Statement: Data and material are available from the authors upon request.

Conflicts of Interest: The authors declare no conflict of interest.

Code Availability: Code is available from the authors upon request.

\section{References}

1. Friedman, M. A Theory of the Consumption Function; Princeton University Press: Oxford, UK, 1957.

2. Camacho-Otero, J.; Boks, C.; Pettersen, I.N. Consumption in The Circular Economy: A Literature Review. Sustainability 2018, 10, 2758. [CrossRef]

3. Schor, J. Debating the Sharing Economy; Great Transition Initiative: Cambridge, MA, USA, 2014; pp. 1-19.

4. Ertz, M.; Durif, F.; Arcand, M. Collaborative Consumption: Conceptual Snapshot at a Buzzword. J. Entrep. Educ. 2016, 19, 1-23. [CrossRef]

5. Jurgilevich, A.; Birge, T.; Kentala-Lehtonen, J.; Korhonen-Kurki, K.; Pietikäinen, J.; Saikku, L.; Schösler, H. Transition towards Circular Economy in The Food System. Sustainability 2016, 8, 69. [CrossRef]

6. Arsova, S.; Genovese, A.; Ketikidis, P.H.; Alberich, J.P.; Solomon, A. Implementing Regional Circular Economy Policies: A Proposed Living Constellation of Stakeholders. Sustainability 2021, 13, 4916. [CrossRef]

7. European Commission. The Sharing Economy: Accessibility Based Business Models for Peer-to-Peer Markets; Business Innovation Observatory; European Commission: Brussels, Belgium, 2013; p. 2.

8. Kirchherr, J.; Reike, D.; Hekkert, M. Conceptualizing the Circular Economy: An Analysis of 114 definitions. Resour. Conserv. Recycl. 2017, 127, 221-232. [CrossRef]

9. Preston, F. A Global Redesign? Shaping The Circular Economy. Chatham House Briefing Paper No EERG BP 2012/02. 2012. Available online: https:/ / www.chathamhouse.org/2012/03/global-redesign-shaping-circular-economy (accessed on 10 September 2021).

10. Roos Lindgreen, E.; Salomone, R.; Reyes, T. A critical Review of Academic Approaches, Methods and Tools to Assess Circular Economy at The Micro Level. Sustainability 2021, 12, 4973. [CrossRef]

11. Lettau, M.; Ludvigson, S.C. Consumption, Aggregate Wealth, and Expected Stock Returns. J. Financ. 2001, 56, 815-849. [CrossRef]

12. Apergis, N.; Miller, S.M. Consumption Asymmetry and the Stock Market: Empirical Evidence. Econ. Lett. 2006, 93, 337-342. [CrossRef]

13. Fratzscher, M.; Straub, R. Asset Prices, News Shocks and The Current Account. CEPR Discussion Paper No 8080. 2010. Available online: http:/ / www.cepr.org/active/publications/discussion_papers/dp.php?dpno=8080 (accessed on 10 September 2021).

14. Koivu, T. Monetary Policy, Asset Prices and Consumption in China. Econ. Syst. 2012, 36, 307-325. [CrossRef]

15. Sousa, R.M. Wealth Effects on Consumption: Evidence from the Euro Area. Banks Bank Syst. 2010, 5, 78-87.

16. Binay, S.; Salman, F. A Critique of the Turkish Real Estate Market. Turkish Economic Association Discussion Paper No $2008 / 8$. 2008. Available online: http:/ / tek.org.tr/dosyalar/critique_6may2008.pdf (accessed on 3 June 2018).

17. Aydede, Y. Aggregate Consumption Function and Public Social Security: The First Time Series Study for a Developing Country, Turkey. Appl. Econ. 2007, 40, 1807-1826. [CrossRef]

18. Uluengin, B.; Yentürk, N. Impacts of Capital Inflows on Aggregate Spending Categories: The Case of Turkey. Appl. Econ. 2001, 33, 1321-1328. [CrossRef]

19. Çimenoğlu, A.; Yentürk, N. Effects of International Capital Inflows on the Turkish Economy. Emerg. Mark. Financ. Trade 2005, 41, 90-109. [CrossRef] 
20. Campbell, J.Y. Stock Returns and the Term Structure. J. Financ. Econ. 1987, 18, 373-399. [CrossRef]

21. Elmendorf, D.W. The Effect of Interest-Rate Changes on Household Saving and Consumption: A Survey. Board of Governors of the Federal Reserve System, Finance and Economics Discussion Series (FEDS). 1996. Available online: https: / /www.federalreserve. gov/pubs/feds/1996/199627/199627pap.pdf (accessed on 3 June 2018).

22. Wilcox, D.W. Interest Rates and Consumption: A Classical Analysis; Federal Reserve Board: Washington, DC, USA, 1993.

23. Campbell, J.Y.; Mankiw, N.G. Consumption, Income and Interest Rates: Reinterpreting the Time Series Evidence. NBER Macroecon. Annu. 1989, 4, 185-216. [CrossRef]

24. Nakajima, J. Time Varying Parameter VAR Model with Stochastic Volatility: An Overview of Methodology and Empirical Applications. Monet. Econ. Stud. 2011, 2, 107-142.

25. Sims, A.C. Macroeconomics and Reality. Econometrica 1980, 48, 1-48. [CrossRef]

26. Primiceri, G.E. Time Varying Structural Vector Autoregressions and Monetary Policy. Rev. Econ. Stud. 2005, 72, 821-852. [CrossRef]

27. Dickey, D.; Fuller, W. Likelihood Ratio Statistics for Autoregressive Time Series with A Unit Root. Econometrica 1981, 49, 1057-1072. [CrossRef]

28. Phillips, P.C.; Perron, P. Testing For a Unit Root in Time Series Regression. Biometrika 1988, 75, 335-336. [CrossRef]

29. Kwiatkowski, D.; Phillips, P.; Schmidt, P.; Shin, J. Testing The Null Hypothesis of Stationarity against The Alternative of a Unit Root. J. Econom. 1992, 54, 159-178. [CrossRef]

30. Elliot, G.; Rothenberg, T.J.; Stock, J.H. Efficient Tests for An Autoregressive Unit Root. Econometrica 1996, 64, 813-836. [CrossRef]

31. Ng, S.; Perron, P. Lag Length Selection and The Construction of Unit Root Tests with Good Size and Power. Econometrica 2001, 69, 1519-1554. [CrossRef]

32. Johansen, S. Statistical Analysis of Cointegration Vectors. J. Econ. Dyn. Control. 1988, 12, 231-254. [CrossRef]

33. Johansen, S. Estimation and Hypothesis Testing of Cointegration Vectors in Gaussian Vector Autoregressive Models. Econometrica 1991, 59, 1551-1580. [CrossRef]

34. Johansen, S.; Juselius, K. Maximum Likelihood Estimation and Inference on Cointegration—With applications to The Demand for Money. Oxf. Bull. Econ. Stat. 1990, 52, 169-210. [CrossRef]

35. Pesaran, M.H.; Shin, Y.; Smith, R.J. Bounds testing approaches to the analysis of level relationships. J. Appl. Econom. 2001, 16, 289-326. [CrossRef]

36. Kripfganz, S.; Schneider, D.C. Response surface regressions for critical value bounds and approximate p-values in equilibrium correction models. Oxf. Bull. Econ. Stat. 2020, 82, 1456-1481. [CrossRef]

37. Enders, W. Applied Econometric Time Series, 4th ed.; John Wiley: Hoboken, NJ, USA, 2015.

38. Geweke, J. Evaluating the accuracy of sampling-based approaches to the calculation of posterior moments. In Bayesian Statistics; Bernado, J.M., Berger, J.O., Dawid, A.P., Smith, A.F.M., Eds.; Oxford University Press: New York, NY, USA, 1992; Volume 4, pp. 169-188.

39. Rodrik, D. The Turkish Economy after the Crisis. Ekonomi-tek 2012, 1, 41-61.

40. Özatay, F. The 1994 Currency in Turkey. Policy Reform 2000, 3, 327-352. [CrossRef]

41. Özatay, F.; Sak, G. Banking Sector Fragility and Turkey's 2000-01 Financial Crisis; Brookings Trade Forum; Brookings Institution Press: Washington, DC, USA, 2002; pp. 121-172.

42. Krugman, P. The Great Recession versus the Great Depression. The New York Times, 20 March 2009. Available online: https: / / krugman.blogs.nytimes.com/2009/03/20/the-great-recession-versus-the-great-depression/(accessed on 3 June 2018). 